\title{
Marketing Efficiency of Date in Khartoum State, Sudan
}

\author{
Abda Abdalla Emam ${ }^{1} \&$ Wafa Abd-Alrhaim Abu-Algasim ${ }^{2}$ \\ ${ }^{1}$ Department of Agri-Business and Consumer Science, Faculty of Agriculture and Food Science, King Faisal \\ University, Kingdom of Saudi Arabia \\ ${ }^{2}$ Minstry of Agriculture, Animal Resources and Irregation, Sudan \\ Correspondence: Abda Abdalla Emam, Department of Agri-Business and Consumer Science, Faculty of \\ Agriculture and Food Science, King Faisal University, Kingdom of Saudi Arabia. E-mail: aaeali@kfu.edu.sa; \\ abdaemam@hotmail.com
}

Received: June 1, 2016

Accepted: November 14, $2017 \quad$ Online Published: April 15, 2018

doi:10.5539/jas.v10n5p384

URL: https://doi.org/10.5539/jas.v10n5p384

\begin{abstract}
The study aimed to measure the marketing efficiency of date at wholesalers in Khartoum State in the year 2013. The study depended mainly on primary data which was collected through questionnaire. About 35 of wholesaler were selected through simple random sampling. Also, secondary data was collected from sources related to topic of the study. The data was analyzed using descriptive statistics tool. Also, quantitative analysis techniques were used to calculate net marketing margins and marketing efficiency for wholesalers. The study revealed that $82.9 \%$ of wholesalers bought the product from local traders. On the other hand, about $68.6 \%$ of wholesalers sold their product to retailers. About 25.30, 33.20, 13.30 and 7.40 SG/Sack represented Gross Marketing Margins for Gondaila, Tomoda, Brakawie and Gawa, respectively. About 25.25, 6.15, -13.75 and -20.65 SG/Sack represented Net Marketing Margins for Gondaila, Tomoda, Brakawie and Gawa, respectively. The Shepherd's Formula indicated that Gondaila, Tomoda, Brakawie and Gawa got marketing efficiency equal to 17.41, 13.09, 06.06 and 02.45 , respectively. The main obstacles that facing wholesalers in marketing of date were follows: transportation cost, taxes, losses and finance. Increasing Net Marketing Margins at wholesaler's Brakawie and Gawa in Khartoum market through reducing marketing costs (minimize economics and normal risks (balance between supply and demand beside control store pest) transportation and taxes cost items). In this efficiency activity, investment and credit services should be encouraged and provided, respectively.
\end{abstract}

Keywords: date, marketing efficiency, marketing margins, Sudan, wholesalers

\section{Introduction}

The date (Phoenix dactyllifera L.) is considered as a symbol of life in the desert, because its tolerance of high temperatures, drought and salinity is more than many other fruit crop plant species. It is one of the oldest trees from which man has derived benefit, and it has been cultivated since ancient times. The only indigenous wild desert plant definitely domesticated in its native harsh environments appears to be the date (Zohary \& Hopf, 2000). The date is a major agricultural crop in the Near East and North Africa, and it has historically been connected with sustaining human life in many of the hot and barren parts of the old world and has become an integral part of the culture and tradition of the people of these regions (Sawaya, 2000). The date retains its value for cultivators as it gives a wide range of products and services, including many necessities of life. The date, the primary product of the palm, is rich in protein, vitamins, and mineral salts. That is why it represents an essential element of diet for the cultivator himself and his animals. All secondary products of the palm result from annual pruning and have essential uses for the cultivator. With an annual production of about 330,000 tons and a date (Phoenix dactylifera L.) population of about 8 million, Sudan ranks number 8 in the list of top date producing countries of the world. However, Sudan has tremendous potential to rank much higher in this scale due to extensive stretches of land between latitude $12^{\circ} \mathrm{N}$ and the Tropic of Cancer, availability of irrigation water and a suitable climate for date production. Dates are traditionally marketed all over the world as a high value confectionery, fresh fruit they remain an important subsistence crop in most of the desert areas (Erskine, 2003). Marketing efficiency can benefit all the key actors in a market chain. An efficient marketing system is essential for earning fair profit for the producers and traders (Janifa et al., 2014). Fewer researches were conducted in date marketing. Hence the present research aimed at shedding light on the marketing efficiency of date in Khartoum state (capital of Sudan). 


\section{Methodology}

According to Emam (2011), marketing margin can be estimated as:

Marketing margin $=$ Selling price - Cost price

Netmarketing margin $=$ Marketing margin - Marketing cost

Net marketing margin for wholesaler $=$ Wholesale marketing margin - Wholesale marketing cost

For the marketing efficiency analysis, it is measured as (Emam, 2010):

Marketing efficiency $=($ Gross marketing margin/Marketing cost $) \times 100$

Also, Shepherd's Formula is used for measuring marketing efficiency as follows (Ugwumba, 2010):

Marketing efficiency $=(\mathrm{V} / \mathrm{I})-1$

Where, $\mathrm{V}=$ Value of goods sold (consumer price); $\mathrm{I}=$ Total marketing cost at specific level of trader.

If the output of calculation is more than one means that the product are efficient in marketing.

\section{Results and Discussion}

\subsection{Socioeconomics Characteristics}

Age: The majority of wholesalers were aged group ranged between 31 and 50 years (Table 1).

Table 1. Distribution of wholesalers according to age groups

\begin{tabular}{lll}
\hline Years & Frequency & Percentage \\
\hline $20-30$ & 05 & 14.3 \\
$31-40$ & 11 & 31.4 \\
$41-50$ & 14 & 40.0 \\
$>50$ & 05 & 14.3 \\
Total & 35 & 100.0 \\
\hline
\end{tabular}

Source: Data collected and calculated, 2013.

Education: The results illustrated that about $5.7 \%, 2.9 \%, 20.0 \%, 45.7 \%$ and $25.7 \%$ were represented illiterate, organic, primary, secondary and university education level for wholesalers, respectively (Table 2). Upton (1987) reported that education has an important influence in managerial ability and decision making. This means that the date marketing is practically done by experienced traders.

Table 2. Distribution of wholesalers according to education levels

\begin{tabular}{lll}
\hline Characters & Frequency & Percentage \\
\hline Illiterate & 2 & 05.7 \\
Organic education & 1 & 02.9 \\
Primary & 7 & 20.0 \\
Secondary & 16 & 45.7 \\
University & 9 & 25.7 \\
Total & 35 & 100.0 \\
\hline
\end{tabular}

Source: Data collected and calculated, 2013.

Marital status: The majority of wholesalers were married (80.0\%) (Table3). 
Table 3. Distribution of wholesalers according to marital status

\begin{tabular}{lll}
\hline Source & Frequency & Percentage \\
\hline Married & 28 & 80.0 \\
Single & 05 & 14.3 \\
Divorced & 02 & 05.7 \\
Total & 35 & 100.0 \\
\hline
\end{tabular}

Source: Data collected and calculated, 2013.

Family Size: The majority of wholesalers (71.3\%) have family size ranged from 1 to 5 persons (Table 4).

Table 4. Family size

\begin{tabular}{lll}
\hline Range & Frequency & Percentage \\
\hline $1-3$ & 12 & 34.2 \\
$3-5$ & 13 & 37.1 \\
$5-7$ & 09 & 25.7 \\
More than 7 & 01 & 02.9 \\
Total & 35 & 100.0 \\
\hline
\end{tabular}

Source: Data collected and calculated, 2013.

Experience: The results recorded that about $74.3 \%$ of wholesales have experience more than six years (Table 5).

Table 5. Distribution of wholesalers according to their experience

\begin{tabular}{lll}
\hline Years & Frequency & Percentage \\
\hline $1-3$ & 06 & 17.1 \\
$3-6$ & 03 & 08.6 \\
More than 6 & 26 & 74.3 \\
Total & 35 & 100.0 \\
\hline
\end{tabular}

Source: Data collected and calculated, 2013.

Source of finance: About $68.6 \%$ and 31.4 of wholesalers were self-finance and others sources of finance, respectively (Table 6).

Table 6. Distribution of wholesalers according to sources of finance

\begin{tabular}{lll}
\hline Source & Frequency & Percentage \\
\hline Self-finance & 24 & 68.6 \\
Loans & 0 & 00.0 \\
Others & 11 & 31.4 \\
Total & 35 & 100.0 \\
\hline
\end{tabular}

Source: Data collected and calculated, 2013.

\subsection{Sources of Date}

$82.9 \%$ and $17.1 \%$ of wholesalers sold date from local traders and producers, respectively (Table 7 ). 
Table 7. Distribution of wholesalers according to sources of date

\begin{tabular}{lll}
\hline Sources & Frequency & Percentage \\
\hline Producer & 06 & 17.1 \\
Local trader & 29 & 82.9 \\
Total & 35 & 100.0 \\
\hline
\end{tabular}

Source: Data collected and calculated, 2013.

\subsection{Distribution of Date}

The results illustrated that about $68.6 \%, 14.3 \%$ and $17.1 \%$ of wholesalers bought date to retailers, consumers and both (consumers and retailers), respectively (Table 8 ).

Table 8. Distribution of date

\begin{tabular}{lll}
\hline Source & Frequency & Percentage \\
\hline Retailer & 24 & 68.6 \\
Consumer & 05 & 14.3 \\
Retailer + Consumer & 06 & 17.1 \\
Total & 35 & 100.0 \\
\hline
\end{tabular}

Source: Field survey, 2013.

\subsection{Analysis of Marketing Cost at Wholesalers of Date}

Marketing costs were the same for different types of date. The marketing cost of date at wholesaler was 27.05 SG/Sack; Rent cost (including losses) (48.69\%), transportation (23.29\%), taxes (12.24\%), handling (3.14\%), and others $(22.57 \%)$ represented the main marketing cost items (Table 9). The results indicated that rent (and losses), transportation and taxes costs represented higher percentages in the marketing costs of date wholesalers. The higher losses were reflected mainly to store pests. This result was assured with previous study (Khairi et al., 2010). The study reported that the store pests cause a lot of damage.

Table 9. Marketing costs at wholesalers of date

\begin{tabular}{lll}
\hline Items & Cost $(\mathrm{G} / \mathrm{sack})$ & Percentage \\
\hline Marketing cost: & 27.050 & 100.00 \\
\hline - Transportation & 06.300 & 23.29 \\
- Handling & 00.850 & 03.14 \\
- Rent Cost (including losses) & $13.170^{*}$ & 48.69 \\
- Taxes & $03.310^{*}$ & 12.24 \\
- Others & $003.420^{*}$ & 12.64 \\
\hline
\end{tabular}

Note. $*=$ cost item (in month in SG)/quantities sold (in month SG/Sack).

Source: Data collected and calculated, 2013.

\subsection{Gross Marketing Margins}

The gross marketing margins were ranked as the descending order for different types of date (Table 10). About 25.30, 33.20, 13.30 and 7.40 SG/Sack represented gross marketing margins for Gondaila, Tomoda, Brakawie and Gawa, respectively.

\subsection{Net Marketing Margins}

About $25.25,6.15,-13.75$ and $-20.65 \mathrm{SG} /$ Sack represented net marketing margins for Gondaila, Tomoda, Brakawie and Gawa, respectively (Table 10). Gondaila, Tomoda got higher and positively net marketing margins while Brakawie and Gawa got lower and negatively net marketing margins. The results of Brakawie and Gawa wholesalers was reflected to the high in marketing costs beside low in gross marketing margins which came as a results of low in selling and buying prices. 


\subsection{Marketing Efficiency}

A market that is efficient does not only bring sellers and buyers together, it enables entrepreneurs to take advantage of opportunities, to innovate and improve in response to demand and price changes (Fakayode et al., 2010). The results indicated that Gondaila got higher marketing efficiency $(193.35 \%)$ followed by Tomoda (122.74\%) then Brakawie (49.17\%) and the last one was Gawa (27.36\%). Also, the marketing efficiency was calculated using Shepherd's Formula. The Shepherd's Formula followed the same sequence of the previous test of efficiency; Table 10 indicated that Gondaila, Tomoda, Brakawie and Gawa got marketing efficiency 17.41, 13.09, 06.06 and 02.45 . The results indicated that the different types of date are efficient in marketing in the study area.

Table 10. Net marketing margins (SG/Sack) and marketing efficiency of different type of datepalm at wholesalers

\begin{tabular}{lllll}
\hline & Gondaila & Tamoda & Brakawie & Gawa \\
\hline Farm gate price & 445.70 & 347.90 & 177.70 & 086.00 \\
Consumer price & 498.00 & 381.10 & 191.00 & 093.40 \\
Gross marketing margin & 052.30 & 033.20 & 013.30 & 007.40 \\
Marketing cost & 027.05 & 027.05 & 027.05 & 027.05 \\
Net marketing margin & 025.25 & 006.15 & -013.75 & -019.65 \\
Marketing efficiency (\%) & 193.35 & 122.74 & 049.17 & 027.36 \\
Marketing efficiency (Shepherd's Formula) & 17.41 & 13.09 & 06.06 & 02.45 \\
\hline
\end{tabular}

Source: Data collected and calculated, 2013.

\subsection{Marketing Constraints}

Many constraints that facing traders of such commodity were recorded. The results illustrated that about $42.9 \%$, $25.7 \%, 20.0 \%$ and $11.4 \%$ of wholesalers face obstacles on others (store pests (losses) and flood in supply), transportation, taxes and finance, respectively (Table 11).

Table 11. Distribution of date wholesalers according to marketing constraints

\begin{tabular}{lll}
\hline Constraints & Frequency & Percentage \\
\hline Transportation & 09.0 & 25.7 \\
Finance & 04.0 & 11.4 \\
Taxes & 07.0 & 20.0 \\
Others* & 15.0 & 42.9 \\
\hline
\end{tabular}

Note. $*$ means store pest (losses) and higher in supply.

Source: Data collected and calculated, 2013.

\section{Recommendations}

Increasing net marketing margins at wholesalers' Brakawie and Gawa in Khartoum market through reducing marketing costs. Minimize economics and normal risks (balance between supply and demand beside control store pest), transportation cost and taxes must be insured. Provision of credit services should be done. Also, encourage investment in this efficiency activity was recommended.

\section{References}

Emam A. A. (2011). Evaluating of Marketing Efficiency of Tomato in Khartoum State, Sudan. Journal of Agriculture \& Social Sciences, 7(1), 21-24.

Emam, A. A. (2010). Marketing Economics of Meat Poultry in Khartoum State, Sudan. Continental Agricultural Economics, 4, 26-31.

Erskine, W., Moustafa, A. T., Osman, A. E., Lashine, Z., Nejatian, A., Badawi, T., \& Ragy, S. M. (2003). Date in the GCC countries of the Arabian Peninsula. Retrieved from http://www.icarda.org/aprp/Datepalm/ introduction/intro-body.htm 
Fakayode, S. B., Omotesho, O. A., Babatunde, R. O., \& Momoh, A. A. (2010). The Sweet Orange Market in Nigeria, How Viable? Research Journal of Agricultural and Biological Sciences, 6(4), 395-400.

Janifa, U. A., Omar, Md. I., Sabur, S. A., Moniruzzaman, M., \& Haque, Md. S. (2014). Analysis of Marketing Function, Marketing Efficiency and Spatial Co-Integration of Rohu (Labeo rohita) Fish in Some Selected Areas of Bangladesh. J Bus Fin Aff, 3, 123. https://doi.org/10.4172/2167-0234.1000123

Khairi, M. M. A., Elhassan, M. I., Bashab, F. A., Zaid, A., \& Alhadrami, G. A. (2010). The Status of Date Cultivation and Date Production in Sudan. Acta Horticulturae, 13(10), 1197-206. https://doi.org/10.17660/ ActaHortic.2010.882.2

Sawaya, W. N. (2000). Proposal for the Establishment of a Regional Network for Date-Palm in the Near East and North Africa. A draft for discussion, FAO/RNE.

Ugwumba, C. O., \& Okoh, R. N. (2010). Price Spread and the Determinants of Catfish Marketing Income in Anambra State, Nigeria. Journal of Agriculture \& Social Sciences, 6, 73-78.

Upton, M. (1987). African farm management. Cambridge University Press.

Zohary, D., \& Hopf, M. (2000). Domestication of Plants in the Old World (3rd ed.). Oxford University Press, Oxford, UK.

\section{Copyrights}

Copyright for this article is retained by the author(s), with first publication rights granted to the journal.

This is an open-access article distributed under the terms and conditions of the Creative Commons Attribution license (http://creativecommons.org/licenses/by/4.0/). 